\title{
Organizational Culture, Organizational Structure and Human Resource Management as Bases for Business Process Orientation and their Impacts on Organizational Performance
}

\author{
Nathália de Melo Santos ${ }^{\dagger}$ \\ Universidade Federal de Minas Gerais - UFMG \\ Marcelo Bronzo ${ }^{\Omega}$ \\ Universidade Federal de Minas Gerais - UFMG \\ Marcos Paulo Valadares de Oliveira ${ }^{\#}$ \\ Universidade Federal do Espírito Santo - UFES \\ Paulo Tarso Vilela de Resende ${ }^{ \pm}$ \\ Fundação Dom cabral - FDC
}

\begin{abstract}
This article presents the main findings of a survey conducted with the aim of describing the interplay of the variables organizational structure, organizational culture and human resource management - considering the assumptions of the business process orientation (BPO) approach - and of identifying the relationship between these constructs and organizational performance, based on the four critical dimensions of the balanced scorecard technique: financial, customer/market, processes/capabilities and learning/growth. We used data from a sample of 368 medium and large Brazilian companies. By means of structural equations modeling we analyzed the associations between the constructs of the proposed nomothetic model. The results point to the existence of positive and statistically significant associations between the constructs investigated, except for the relationship between organizational structure and organizational performance. The results, including with respect to the relatively weak association between elements of organizational structure and performance, suggest that BPO initiatives can have a strong effect on organizational performance, adding to discussions of the theme.
\end{abstract}

Keywords: Business process management. Human resource management. Organizational structure. Organizational culture. Organizational performance.

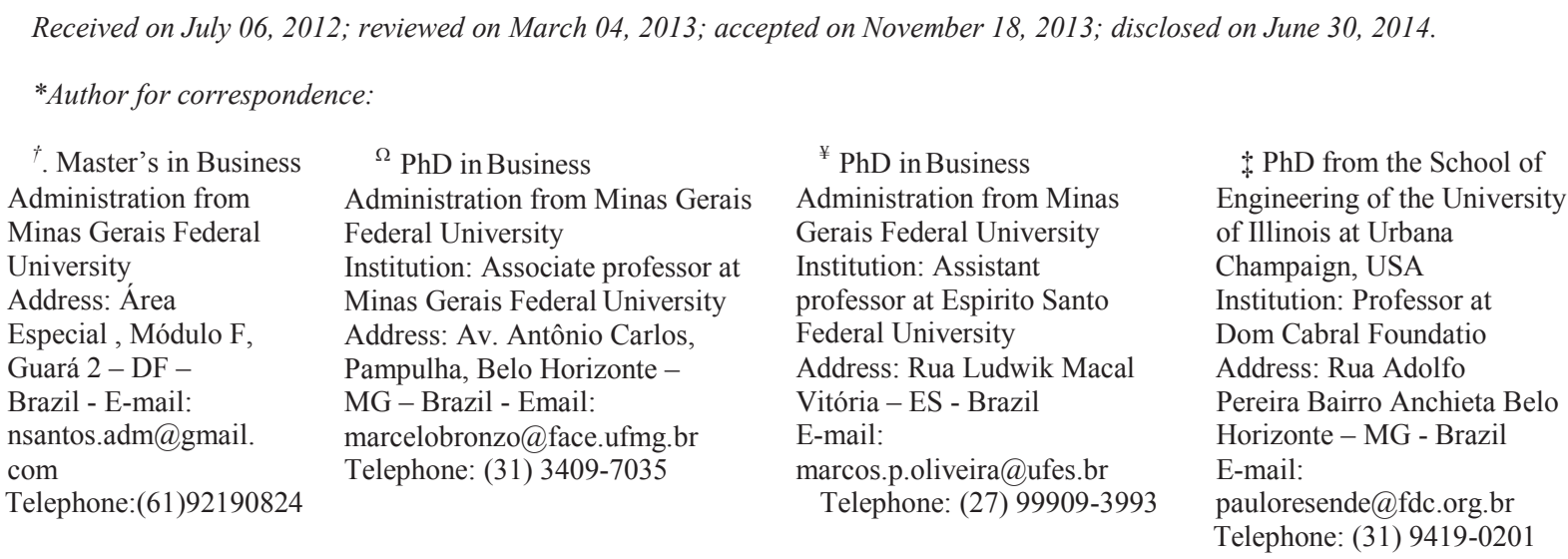

Note from the Editor: This article was accepted by Emerson Mainardes.

(cc) $\mathrm{EY}$

This article has a Creative Commons License - Attribution 3.0 Not Adapted. 


\section{INTRODUCTION}

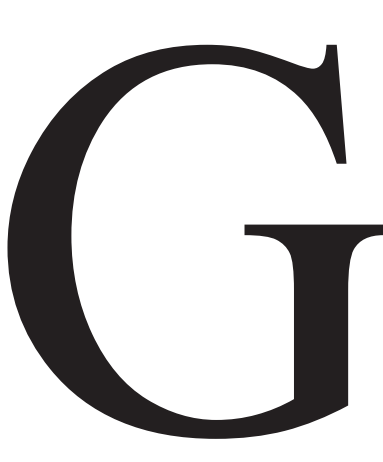

lobal competition and the increased expectations of customers require companies to attain superior levels of efficiency and quality, as well as flexibility, to keep abreast of the changes that are occurring in the business world. This requires simplification of operations and integration of business practices (SIDOROVA; ISIK, 2010; WILLAERT et al., 2007; BITITCI et al., 1999; LOVE et al., 1998).

As a consequence, business process management (BPM) has been developed as an attractive solution developed for various organization questions, supported by the concept of business process orientation (BPO). BPM can be defined as a disciplined approach to identify, design, execute, document, measure, monitor and control processes, automated or not, to attain targeted results consistently, in line with the organization's strategic objectives (ABPMP, 2009). In turn, BPO is defined as "an organization that, in all its thinking, emphasizes process as opposed to hierarchies with special emphasis on outcomes and customer satisfaction" (MCCORMACK et al., 2003, p. 21).

Projects for processes should cover social and technical aspects, so as to consider interdependent elements of the organization that support their implementation, namely: organizational activities, structure, people (culture/behavior) and technology (LOVE et al., 1998). Congruence of these dimensions is an important condition for the effectiveness of business processes. Among many studies of the theme, Davenport (1993) and Hammer (1996) stress this perspective by identifying that a substantial portion of innovations in processes come from a combination between information technology and changes in organizational and human resources - specifically the structure and policies on human resources.

Corroborating these ideas, Willaert et al. (2007) pointed out the need for a holistic vision about process orientation, covering guidance provided to customers, vision of the process, organizational structure, performance of the process, culture, values and beliefs, human resource management, information technology and the perspective of suppliers. It can thus be seen that this field encompasses knowledge and competencies from several domains, making it comprehensive and holistic in character (WILLAERT et al., 2007; CAKAR et al., 2003; HAMMER, 2001; SKRINJAR; TRKMAN, 2013).

There are relatively few works that have investigated business processes through truly interdisciplinary approaches (LOVE et al., 1998; COOPER et al., 1997; DAVENPORT, 1993; ZUCCHI; EDWARDS, 1999), and more specifically, articles aimed at systematically 
investigating the effects of the interplay of (i) organizational structure, (ii) organizational culture, beliefs and values and (iii) human resource management on organizational performance.

Our aim here is precisely this, to investigate the association between the dimensions in question (organizational structure, organizational culture and human resource management), from the perspective of BPO, and organizational performance, based on the four critical areas of BSC: financial, customer/market, processes/capabilities and learning/growth. The central question that guided our research was to understand to what extent a greater orientation toward business processes can produce positive effects on organizational performance, and to quantify this effect by means of structural equations modeling.

We therefore sought to investigate the relevance of different human and structural attributes when searching for greater process orientation. Empirical evidence that the constructs of the research model are interrelated would help managers reach decisions regarding structuring organizational change processes focused on BPO. We intend to indicate the dimensions human resource management, organizational culture and organizational structure, not in detriment to technical aspects, but rather to complement them. All these concepts addressed here are presented from the standpoint of management by processes, without any intention of delving more deeply into the respective areas.

This paper is organized into five sections, including this introduction. The second section sets out the theoretical framework, where we summarize the main concepts used. The third covers the methodology applied to reach the proposed objectives, while the fourth presents the analysis of the data and results obtained. The fifth section presents our conclusions and some suggestions for future research.

\section{THEORETICAL FRAMEWORK}

\subsection{BUSINESS PROCESSES}

Business processes determine how companies perform their work of delivering value to their customers. Hence, a business process can be defined as a task leading from one point to another that delivers value to customers (ABPMP, 2009). In other words, it is the way an organization performs its work, represented by a set of structures and interconnected activities, which are carried out from inputs to attain a specific objective related to the market or a specific client (outputs), whether internal or external (DAVENPORT, 2005; BRONZO; OLIVEIRA, 2008; HAMMER, 2001; ARMISTEAD; MACHIN, 1997; ZAIRI, 1997; MCCORMACK; JOHNSON, 2001). 


\subsubsection{Business Process Management and Business Process Orientation}

As stated in the introduction, the definitions of BPM and BPO are interconnected, since the former can be considered a condition of the latter. From this perspective, BPM is defined as an approach that includes various aspects and that depends on different strategic and operational elements and the use of modern tools and techniques, with the involvement of people, to meet the needs of clients satisfactorily in the best way possible (ZAIRI, 1997).

Corroborating that perspective, Hammer (1996), through the "business diamond", described an organization in terms of four main elements: business processes; organizational activities and structure; management and measurement systems; and values and beliefs of employees. According to him, the management model adopted and measurement systems reflect, model and perpetuate the values and beliefs of employees, which in turn support the company's business processes and influence how jobs are carried out. These elements are interdependent and influence each other.

According to Skrinjar \& Trkman (2013), BPM includes many practices from different fields of study, and can be identified as a set of practices, methods, technologies and tools organized in structured, analytic and inter-functional form, with the aim of assuring ongoing improvements of processes. Hence, the use of practices based on BPM enhances BPO, which in turn leads to better organizational performance. An increase in the level of process orientation in the organization affects the organizational structures, human resource management policies and the organizational culture, in support of a broad vision of business processes.

In this context, different authors have stated that neglecting the human aspects of change is one of the causes of failure in the implementation of BPM initiatives (VIAENE et al., 2010; DAVENPORT, 1993). Zucchi \& Edwards (1999) stressed that one of the main difficulties that must be overcome for successful implementation of BPM is the apparent gap related to the human aspects, found both in the current literature and in the efforts of firms that are trying to implement BPM. Albuquerque (2002) observed the importance of undertaking an internal analysis focused on human dimensions, namely culture and the interaction of people with the organizational structure, as well as the human resource management strategy, all of which will interact and contribute to achievement of the firm's strategic objectives. 


\subsection{HUMAN RESOURCE MANAGEMENT}

To clarify the role of the individual in management by processes, various studies have shown that aspects related to human resource management - "training and learning by doing" and "management of resistance to change" - are key factors for successful implementation of BPO (BALZAROVA et al., 2004). This is a collaborative approach, in which work must be carried out by teams, with focus on the customers, encompassing all activities, point by point (HAMMER, 2001).

Since BPO is considered an approach that integrates the entire organization, it must be understood by all employees (LEE; DALE, 1998). For this reason, administering a company under the prism of BPO/BPM is one of the main challenges of effective management of human resources (HR), demanding a thorough understanding of the effect of changes in processes on employees (GONÇALVES, 2000a; BALZAROVA et al., 2004). The adaptation occurs when the employees adopt new mental models, attitudes and values, which are stimulated by the organization (GONÇALVES, 2000a).

A way to institutionalize process orientation is to create measurement systems based on processes that are connected to employee compensation policies (HAMMER, 2001), as observed by Byrne (1992) and Willaert et al. (2007). Compensation can be tied to the employees' performance of the processes in which they take part, stimulating them to achieve the best possible results. For this it is essential for people to be trained and informed about how to improve processes and to think in terms of processes (WILLAERT et al., 2007). Periodic courses and training programs aimed at management by processes should be offered, to enable continuous improvement and adaptation regarding the need to adopt changes in processes or implement new ones (SKRINJAR; TRKMAN, 2013).

Faced with changes, companies have created a new job function: process owner. This new position is considered a key element in any process improvement project based on BPO, with this person being responsible for all the results of the process for which he or she was designated (KOHLBACHER, 2010; SKRINJAR; TRKMAN, 2013).

Previously, Huselid (1995) had stated that human resource management policies can influence firms' performance by providing organizational structures that encourage participation among employees and that allow them to improve the way they work. Crossfunctional teams, job rotation, and quality circles are examples of these structures. In this sense, the relevant principle here is that human resource management practices and policies can affect the individual performance of workers by the influence exerted on their skills and 
motivation. An equally relevant influence can be identified in the dimension of organizational structures, since certain characteristics of these structures can favor the improvement of the way jobs are done (HUSELID, 1995).

\subsection{ORGANIZATIONAL CULTURE}

Culture refers to the "pattern of development reflected in a society's system of knowledge, ideology, values, laws and day-to-day rituals" (MORGAN, 2002, p. 115). In discussing the overview of culture in the ambit of organizations, Martin (1992) stated that organizational culture is composed of various elements, including informal practices such as behavioral norms, the organizational stories employees tell to explain how things are done in the firm, rituals, tasks, payment systems, jargon understood only by those in the organization, among others. This set of elements represents some of the many manifestations of organizational culture and constitutes the patterns or configurations of interpretations, as well as the ways goals are achieved.

In the context of process orientation, McCormack \& Johnson (2001) stated that managers should guide the creation of an organizational culture with characteristics that valorize aspects of cross-functional integration and focus on the customer, together with systematic thinking and processes. Process orientation should be part of the organizational culture and aspects of this orientation, such as focus on customers, should be reflected in the beliefs, values and principles to which the organization is publicly committed (WILLAERT et al., 2007).

Culture is not something imposed on a social situation; it develops during the course of social integration (MORGAN, 2002). Therefore, an important aspect of process orientation with cultural implications is the presence of inspiring leaders and executive support. Senior managers are responsible for directing the organization around the idea of process orientation (TENNER; DETORO, 2000).

In this respect, it is necessary for managers to discuss themes related to business processes in their meetings and to disseminate among employees a vision of the company as a set of interconnected processes that must work in harmony with the strategic goals. In other words, the departmental objectives should be in line with those of the organization as a whole (SKRINJAR; TRKMAN, 2013). To reinforce these ideas, it is important for managers to hold periodic meetings to foster the integration of these processes through absorption of the principles of process orientation. 


\subsection{ORGANIZATIONAL STRUCTURE}

Organizational structure can be defined as the design by means of which the company is administered (CHANDLER, 1962). It has three basic functions: to produce products and achieve goals; to minimize or regulate the influence of individuals' variations in the organization; and to represent the context in which power is exercised, decisions are made and activities are carried out (HALL, 1984). According to Mintzberg (2008, p. 12), organizational structure can be defined as the way that "labor is divided into distinct tasks and then its coordination achieved among those tasks."

In this context, BPO is a management approach that depends on a restructuring that shapes the organization around its processes, teams and results, relying on coordinated management of the firm's activities - especially those carried out by different departments. For this purpose, teams are created with people formally designated in the organizational chart, with responsibility for managing the interdepartmental processes and projects, as well as for proposing improvements.

From this perspective, the organization is viewed as a series of interconnected functional processes in which the policies and guidelines are defined by upper management, although the authority to examine, challenge and change working methods is delegated to cross-functional working teams. The concern for organizational structure is to facilitate the flows of activities between the different areas, something that demands the implementation of changes in human resource policies, so that employees have a greater participation in the final result (DETORO; MCCABE, 1997; GONÇALVES, 2000b).

\subsection{SYSTEMS TO MEASURE ORGANIZATIONAL PERFORMANCE}

In the traditional view, performance measures are an integral element of planning and cycle control, because they are a way to capture data on performance that can be used to support decisions (NEELY et al., 1997). Brewer \& Speh (2000) and Chen, Mattioda \& Daugherty (2007) argue that supply chain performance measures can provide a perspective of processes, which requires a more holistic vision than the traditional emphasis on individual functions. In structuring performance measures, firms should avoid taking a narrow and onedimensional focus, because this weakens the measurement system (Neely et al., 2000), and need to use robust measures.

In this context, the balanced scorecard (BSC) technique is a tool to complement measurement of past financial performance with metrics that look to future performance (KAPLAN; NORTON, 1996). It is widely used by companies as a tool to assess and manage 
performance (BRAAM; NIJSSEN, 2004). Its strategy emphasizes that financial and nonfinancial measures should both be part of the information system for employees at all levels because this helps attain superior performance.

The BSC model therefore integrates measures of business strategies in at least four dimensions: financial; customer; process; and learning and growth. These four perspectives provide a framework for BSC, by means of which it is possible to translate strategy into operational terms. Companies can use it to clarify their vision and strategy; communicate it and connect strategic objectives and measures; plan, specify targets, align strategic initiatives; and improve strategic feedback and learning (KAPLAN; NORTON, 1996).

\subsection{CONCEPTUAL MODEL}

Table 1 presents the constructs investigated in this study, together with the variables.

Each construct has an associated abbreviation in parentheses.

\begin{tabular}{|c|c|c|}
\hline Constructs & Variables & Description \\
\hline \multirow{4}{*}{$\begin{array}{l}\text { Organizational } \\
\text { Structure } \\
\quad \text { (OS) }\end{array}$} & OS1 & $\begin{array}{l}\text { The firm's organizational structure facilitates integration of the flow of } \\
\text { activities between areas/departments. }\end{array}$ \\
\hline & OS2 & $\begin{array}{l}\text { The firm's organizational structure contains teams responsible for } \\
\text { coordinating inter-departmental projects or processes. }\end{array}$ \\
\hline & OS3 & $\begin{array}{l}\text { The firm has people responsible for managing processes who are formally } \\
\text { represented in the organizational chart. }\end{array}$ \\
\hline & OS4 & $\begin{array}{l}\text { The firm's organizational structure has an area or department responsible for } \\
\text { proposing improvements in business processes. }\end{array}$ \\
\hline \multirow{4}{*}{$\begin{array}{l}\text { Human resource } \\
\text { managements } \\
\text { (HRM) }\end{array}$} & HRM1 & $\begin{array}{l}\text { Employees participate in periodic courses and training programs to enhance } \\
\text { their knowledge of managing processes. }\end{array}$ \\
\hline & HRM2 & $\begin{array}{l}\text { When there is a change in a process or implementation of a new process, the } \\
\text { employees are sufficiently trained before they start performing their } \\
\text { activities in this process. }\end{array}$ \\
\hline & HRM3 & $\begin{array}{l}\text { Part of the employees' compensation is tied in some way to the performance } \\
\text { of the processes in which they are active. }\end{array}$ \\
\hline & HRM4 & $\begin{array}{l}\text { For the most part, tasks are executed valorizing independence of employees, } \\
\text { allowing them to make certain types of decisions in carrying out their daily } \\
\text { tasks. }\end{array}$ \\
\hline \multirow{5}{*}{$\begin{array}{l}\text { Organizational } \\
\text { Culture } \\
\quad \text { (OC) }\end{array}$} & $\mathrm{OC} 1$ & $\begin{array}{l}\text { Concepts such as process orientation and excellence in performing processes } \\
\text { are discussed by management at periodic meetings. }\end{array}$ \\
\hline & OC2 & $\begin{array}{l}\text { In general, the employees understand the nature of the business as a series of } \\
\text { interconnected processes. }\end{array}$ \\
\hline & $\mathrm{OC} 3$ & $\begin{array}{l}\text { The company is able to suitably manage conflicts between functions (or } \\
\text { departments) and minimize resistance to changes in processes, when } \\
\text { necessary. }\end{array}$ \\
\hline & $\mathrm{OC} 4$ & $\begin{array}{l}\text { Alignment exists in the company between the strategic objectives of its } \\
\text { functional areas (marketing, sales, production and finance, among others). }\end{array}$ \\
\hline & OC5 & $\begin{array}{l}\text { Managers hold meetings with the aim of improving the integration of the } \\
\text { flows of activities associated with the various functional areas of the } \\
\text { business (marketing, sales, production, finance, others). }\end{array}$ \\
\hline \multirow{2}{*}{$\begin{array}{l}\text { Financial } \\
\text { Performance } \\
\quad(\text { FP) }\end{array}$} & FP1 & $\begin{array}{l}\text { From the standpoint of profitability and revenue growth, the financial results } \\
\text { for the past two years are satisfactory and meet the targets of the firm's } \\
\text { strategic planning. }\end{array}$ \\
\hline & FP2 & $\begin{array}{l}\text { From the standpoint of efficiency in reducing costs, the financial results for } \\
\text { the past two years are satisfactory and meet the targets of the firm's strategic } \\
\text { planning. }\end{array}$ \\
\hline
\end{tabular}




\begin{tabular}{|c|c|c|}
\hline \multirow{4}{*}{$\begin{array}{l}\text { Customer and } \\
\text { Market } \\
\text { Performance } \\
\text { (CMP) }\end{array}$} & CMP1 & Most of the company's customers are loyal. \\
\hline & CMP2 & The company manages to attract new customers. \\
\hline & CMP3 & $\begin{array}{l}\text { The company is competitive in terms of sales and market share in its } \\
\text { segments. }\end{array}$ \\
\hline & CMP4 & $\begin{array}{l}\text { The company manages to maintain the satisfaction level of its customers in } \\
\text { the various markets where it acts. }\end{array}$ \\
\hline \multirow{7}{*}{$\begin{array}{l}\text { Processes and } \\
\text { Capabilities } \\
\text { Performance } \\
\text { (PCP) }\end{array}$} & PCP1 & $\begin{array}{l}\text { The company is consistent in filling the orders of its customers, i.e., it } \\
\text { manages to deliver what was promised within the agreed time limits. }\end{array}$ \\
\hline & PCP2 & The company has managed to reduce the time it takes to fill orders. \\
\hline & PCP3 & $\begin{array}{l}\text { The company has managed to reduce the time it takes to develop new } \\
\text { products. }\end{array}$ \\
\hline & PCP4 & $\begin{array}{l}\text { The company has managed to develop and manage its external processes } \\
\text { with suppliers adequately. }\end{array}$ \\
\hline & PCP5 & $\begin{array}{l}\text { The company has managed to develop and manage its external processes } \\
\text { with customers adequately. }\end{array}$ \\
\hline & PCP6 & $\begin{array}{l}\text { The company's human capabilities are adequate in relation to the strategic } \\
\text { guidelines for planning the business. }\end{array}$ \\
\hline & PCP7 & $\begin{array}{l}\text { The company's technological capabilities are adequate in relation to the } \\
\text { strategic guidelines for planning the business. }\end{array}$ \\
\hline \multirow{4}{*}{$\begin{array}{l}\text { Learning and } \\
\text { Growth } \\
\text { Performance } \\
\text { (LGP) }\end{array}$} & LGP1 & $\begin{array}{l}\text { The company has employees who have high capability or potential for } \\
\text { professional growth in their respective areas of competence. }\end{array}$ \\
\hline & LGP2 & $\begin{array}{l}\text { Most of the employees are highly committed to the company's performance } \\
\text { targets. }\end{array}$ \\
\hline & LGP3 & $\begin{array}{l}\text { The company continuously tries to manage knowledge from execution of its } \\
\text { processes. }\end{array}$ \\
\hline & LGP4 & $\begin{array}{l}\text { The employees' skills and competencies are adequate to meet its strategic } \\
\text { targets. }\end{array}$ \\
\hline
\end{tabular}

Table 1 - Constructs and Variables

Source: Prepared by the authors, based on the variables presented in Bronzo et al. (2011).

The nomothetic model proposed in this study, based on the BPO perspective, is presented in Figure 1 and is composed of the following constructs: human resource management (HRM), organizational culture (OC), organizational structure (OS) and organizational performance (Performance), reflected in the dimensions: financial performance (FP), customer and market performance (CMP), processes and capabilities performance (PCP) and leaning and growth performance (LGP). The BPO dimensions studied here (OS, HRM and OC) along with the variables were taken from the models of McCormack et al. (2003) and Willaert et al. (2007). The variables that compose the performance dimensions are anchored on the BSC model (KAPLAN; NORTON, 1996) and were summarized and adapted for our objectives. 


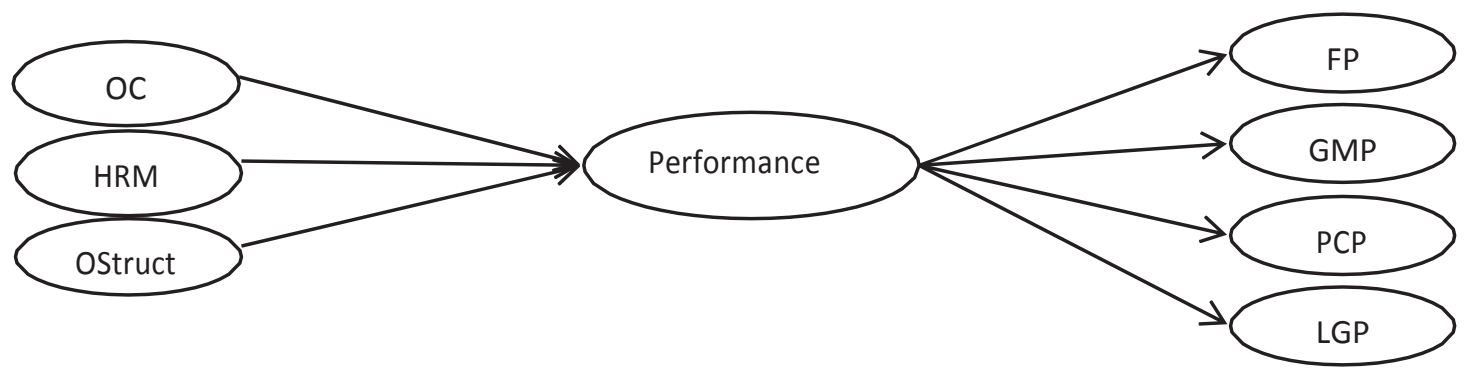

Figure 1- Hypothetical Model of the Constructs Organizational Structure, Organizational Culture, Human Resource Management and Organizational Performance Source: Prepared by the authors.

To guide the conception of a methodological structure to investigate the research questions, we formulated the following hypotheses:

\begin{tabular}{|c|l|}
\hline Hypothesis & \multicolumn{1}{c|}{ Description } \\
\hline $\mathbf{H 1}$ & There are relations between the constructs organizational structure and organizational culture. \\
\hline $\mathbf{H} 2$ & $\begin{array}{l}\text { There are relations between the constructs organizational culture and human resource } \\
\text { management. }\end{array}$ \\
\hline $\mathbf{H 3}$ & $\begin{array}{l}\text { There are relations between the constructs organizational structure and human resource } \\
\text { management. }\end{array}$ \\
\hline $\mathbf{H 4}$ & $\begin{array}{l}\text { The constructs organizational structure, organizational culture and human resource management } \\
\text { influence the performance of the companies in the sample. }\end{array}$ \\
\hline
\end{tabular}

Table 2 - Research Hypotheses

Source: Prepared by the authors.

To test the fit of the proposed hypothetical-relational model proposed to the data, we used the multivariate statistical technique called structural equations modeling (SEM). For this purpose it was necessary to classify the measurement models between reflexive and formative, based on the theory exposed. Therefore, to assess the measurement models that define the relation between the constructs and the manifest variables, we defined the constructs OS, HRM and OC as reflexive, while we considered the other constructs, related to organizational performance - FP, CMP, PCP and LGP - to be formative.

\section{METHODOLOGY}

The data used in this work were gathered through an electronic survey carried out between October and December 2010. We prepared a questionnaire with 89 variables, including information on the characteristics of each firm (e.g., size, sector, annual sales volume). We used a Likert scale of five points, varying from "Totally disagree" (1) to "Totally agree" (5). We sent the questionnaires by e-mail to 2,000 companies in the database of contacts of a large executive education and training organization that is active in Brazil and other South American countries. 
We sent the questionnaires to people working in the areas of operations, logistics, marketing, sales, product return, finance and quality, at the middle or senior management level. During the three months we received responses from 368 companies, broken down by sector into industry (55\%) and services (45\%). Regarding scope of activity, 144 companies (39\%) were active in Brazil and abroad, 81 (22\%) throughout Brazil but not abroad and 15 (4\%) only abroad.

The data analysis was divided into two steps. In the first we carried out an exploratory analysis, preparing the database for the use of multivariate statistical techniques. For this purpose, we used the SPSS $19 \AA$ software. In the second we conducted the multivariate analysis, focusing on the SEM technique, this time relying on the SmartPLS 2.0 M3 software.

\section{PRESENTATION AND ANALYSIS OF THE RESULTS}

\subsection{EXPLORATORY ANALYSIS OF THE DATA}

From the full database we formulated the descriptive statistics for the purpose of better knowledge of the profile of the data in the sample. After concluding the missing data analysis and verifying there were no problems in this respect, we searched for outliers. By means of standardized scores and based on a $Z$ value of 4, given the large sample size (TABBACHNICK; FIDELL, 2007), we did not find any univariate outliers. In turn, we used the $D^{2}$ metric of Mahalanobis to detect multivariate outliers, and found one. According to Hair et al. (2009), multivariate outliers are unique only in the combination of variables, so we decided to keep this observation in the succeeding analyses.

The Shapiro-Wilks and Kolmogorov-Smirnov tests indicated the data were not normally distributed. The adoption of a Likert scale makes it hard to obtain normally distributed data. To test linearity, we calculated Spearman's correlation coefficient between the indicators of the same construct, and all of them were significant at the 5\% level (two-tailed). Given the absence of normality, a condition for use of algorithms base on maximum likelihood, we applied partial least squares (PLS) for the SEM.

\subsection{EVALUATION OF THE MODEL'S CONSTRUCTS}

Dimensionality is obtained with the homogeneity of the items. In other words, basically an instrument that is considered one-dimensional has statistical properties demonstrating that its items are under a single factor or construct. Various procedures have been applied to check the dimensionality of a scale, among them exploratory factor analysis (EFA) (NETEMEYER; BEARDEN; SHARMA, 2003). 
We used EFA for each reflexive construct separately, since our objective was to verify the pertinence of each variable to a specific factor. EFA is valid only for reflexive measurement models, while formative measurement models should be evaluated by SEM. Table 3 presents the different tests applied together with their acceptance parameters (HAIR JR. et al., 2009; TABBACHNICK; FIDELL, 2007).

Table 3 - Criteria for Adequacy of the Factor Solution Found

\begin{tabular}{|l|l|l|l|}
\hline Measure & $\begin{array}{l}\text { Acceptance } \\
\text { parameter }\end{array}$ & Measure & $\begin{array}{l}\text { Acceptance } \\
\text { parameter }\end{array}$ \\
\hline Correlation & $>0.300$ & Factor Loading (FL) & $>0.400$ \\
\hline Bartlett's Test of Sphericity (BTS) & $\mathrm{p}<0.05$ & Explained Variance (EV) & $>60 \%$ \\
\hline $\begin{array}{l}\text { Kaiser-Meyer-Olkin Measure of } \\
\text { Sampling Adequacy (KMO) }\end{array}$ & $>0.500$ & Cronbach's Alpha & $>0.70$ \\
\cline { 2 - 4 } & & Commonality & $>0.500$ \\
\hline
\end{tabular}

Source: Prepared by the authors, based on Hair et al. (2009) and Tabbachnick \& Fidell (2007)

We began the interpretation of the results of the EFA with the OS construct. All the correlations were higher than 0.3 , the resulting KMO was 0.733 and the significance was less than 0.05 for the BTS. The analysis of the commonalities revealed that the variable OS 1 had a value below 0.5 , but its correlation values were higher than 0.3 and its factor loading was greater than 0.6. We therefore opted to maintain this variable in the subsequent analyses. This construct explained $61.57 \%$ of the variance of its indicators.

For the PF construct, the correlation matrix presented values higher than 0.3. The KMO and BTS tests also presented satisfactory results: 0.718 and significance below 0.05 for the BTS. The analysis of commonalities revealed that only the variable HRM3 was lower than

0.5 . Since this variable presented factor loading above 0.6 and values greater than 0.3 in the correlation matrix, we decided to keep it in the subsequent analyses. The HRM construct managed to explain $60.71 \%$ of the variance of the variables.

The correlation matrix of the CO presented values greater than 0.5. The KMO and BTS test values were acceptable: 0.865 for the KMO and significance lower than 0.05 for the BTS. All the commonalities presented values greater than 0.6 and the components matrix presented values higher than 0.78 , indicting strong pairwise relationships between the variables. The construct explained $66.65 \%$ of the variance of the variables.

\subsection{STRUCTURAL EQUATIONS MODELING}

We operationalized this step using the partial least squares (PLS) algorithm, with the SmartPLS ${ }^{\circledR}$ software (RINGLE; WENDE; WILL, 2005). PLS as a method to estimate the parameters of an equation has some advantages that make is suitable for various studies in the area of the social sciences: it does not require the data to be normally distributed; it allows the use of metric or ordinal scales; it favors analysis of formative measurement models; and it has 
a predictive function (HAIR JR.; SARSTEDT; RINGLE, 2011), which suits the objectives of this study.

The PLS path model does not provide any global goodness-of-fit criterion, so assessment of the proposed model consists of a two-step process: evaluation of the outer, or measurement, model; and evaluation of the inner, or structural, model (HENSELER; RINGLE; SINKOVICS, 2009). The analysis carried out in the SmartPLS program used the hierarchical components approach, originally proposed by Wold (1982).

A systematic assessment of the PLS estimates reveals the reliability and validity according to criteria associated with formative or reflexive models. It only makes sense to assess the estimates of the inner path model when the scores calculated for the latent variable show evidence of sufficient reliability and validity (HENSELER; RINGLE; SINKOVICS, 2009). In this context, below we present the criteria that should guide the first step of the analysis, with focus on the reflexive measurement models (Table 4).

\begin{tabular}{|l|l|}
\hline \multicolumn{2}{|c|}{ Evaluation of reflexive measurement models } \\
\hline Composite reliability $\left(\boldsymbol{p}_{c}\right)$ & $\begin{array}{l}\text { The composite validity is a measure of internal consistency and must } \\
\text { not be lower than } 0.6 .\end{array}$ \\
\hline Indicator reliability & Absolute standardized outer loadings should be greater than 0.7. \\
\hline $\begin{array}{l}\text { Average Variance Extracted } \\
(A V E)\end{array}$ & The AVE should be higher than 0.5. \\
\hline Fornell-Larcker criterion (1981) & $\begin{array}{l}\text { Discriminant validity: the AVE of each latent variable should be higher } \\
\text { than the squared correlations with all other latent variables. }\end{array}$ \\
\hline Cross-loadings & $\begin{array}{l}\text { Discriminant validity: if an indicator has a higher correlation with } \\
\text { another latent variable than with its respective latent variable, the } \\
\text { appropriateness of the model should be reconsidered. }\end{array}$ \\
\hline
\end{tabular}

Table 4 - Evaluation Criteria of Reflexive Measurement Models

Source: Adapted from Henseler, Ringle \& Sinkovics (2009, pp. 302-303) and Hair Jr., Sarstedt \& Ringle (2011)

Initially we observed the general quality of the reflexive measurement models. The indicators used obtained adequate levels of reliability and quality of measurement. In relation to the AVE, all the constructs presented values above the suggested level, 0.50, indicating adequacy of the measurement instrument. Regarding the composite reliability, the values of all the constructs were greater than 0.6. Therefore, we believe the values are adequate for the proposed analysis. 
After this step, it was necessary to assess the validity of the constructs according to the degree of congruence between the attribute measured and the attributes intended for measurement (NETEMEYER; BEARDEN; SHARMA, 2003). From the standardized values found for the reliability of the indicators, we concluded that all the variables were within the levels stipulated by these authors. To assure the discriminant validity, we used the crossloadings criterion and the test of Fornell \& Larcker (1981). Both tests confirmed the pertinence of the indicators to the proposed constructs.

After evaluating the reflexive measurement models, we analyzed the formative models, according to the criteria shown in table 5.

\begin{tabular}{|c|l|}
\hline \multicolumn{2}{|c|}{ Evaluation of formative measurement models } \\
\hline Criterion & \multicolumn{1}{c|}{ Description } \\
\hline Nomological validity & $\begin{array}{l}\text { The relationships between the formative index and other constructs in the path } \\
\text { model, which are sufficiently well known from previous research, should be strong } \\
\text { and significant. }\end{array}$ \\
\hline Significance of weights & The estimated weights of formative measurement models should be significant. \\
\hline Multicollinearity & $\begin{array}{l}\text { Any variance inflation factor (VIF) substantially greater than 1 indicates } \\
\text { multicollinearity. It is best to have values }<5 \text {. It can also be evaluated by means of } \\
\text { the tolerance, which should be } r>0.20 .\end{array}$ \\
\hline
\end{tabular}

Table 5 - Evaluation Criteria of Formative Measurement Models

Source: Adapted from Henseler, Ringle \& Sinkovics (2009, pp. 302-303) and Hair, Sarstedt \& Ringle (2011)

By means of analyzing the theoretical framework, which corroborated the statistical relationships tested, it was possible to establish the nomological validity of the formative measurement models. Table 6 reports the weights of the variables in forming the constructs.

Table 6 - Weights of the Variables in Formation of the Constructs

\begin{tabular}{|c|c|c|c|c|c|c|}
\hline \multirow{2}{*}{ Construct } & \multirow{2}{*}{$\mathbf{R}^{2}$} & \multirow{2}{*}{ Indicators } & \multicolumn{4}{|c|}{$\begin{array}{c}\text { Weights of the variables in formation of the constructs (outer } \\
\text { weights) }\end{array}$} \\
\hline & & & LGP & CMP & FP & PCP \\
\hline \multirow{4}{*}{ LGP } & \multirow{4}{*}{0.715218} & LGP1 & 0.1018 & & & \\
\hline & & LGP2 & 0.2575 & & & \\
\hline & & LGP3 & 0.4528 & & & \\
\hline & & LGP4 & 0.3595 & & & \\
\hline \multirow{3}{*}{ CMP } & \multirow{3}{*}{0.716942} & CMP1 & & 0.2266 & & \\
\hline & & CMP2 & & 0.3997 & & \\
\hline & & CMP3 & & 0.1825 & & \\
\hline
\end{tabular}




\begin{tabular}{|c|c|c|c|c|c|}
\hline & & CMP4 & 0.3837 & & \\
\hline \multirow{2}{*}{ FP } & \multirow{2}{*}{0.491816} & FP1 & & 0.3643 & \\
\hline & & FP2 & & 0.7255 & \\
\hline \multirow{7}{*}{ PCP } & \multirow{7}{*}{0.868654} & PCP1 & & & 0.1866 \\
\hline & & PCP2 & & & 0.1408 \\
\hline & & PCP3 & & & 0.1309 \\
\hline & & PCP4 & & & 0.2214 \\
\hline & & PCP5 & & & 0.1887 \\
\hline & & PCP6 & & & 0.2888 \\
\hline & & PCP7 & & & 0.1936 \\
\hline
\end{tabular}

Source: Research data.

The multicollinearity was calculated from the VIF and the tolerance, as suggested by the sources consulted. According to the results, the multicollinearity present was not harmful $(\mathrm{VIF}<5$ and tolerance $>0.20)$.

After concluding the initial analyses of the measurement models, we checked the level of significance of the relationships between the latent variables and their indicators by means of bootstrapping. The result of the T-statistic indicated that all the relationships between the manifest variables were valid at a significance level of 0.01 and 0.05 . The relationship with the variable LGP1 was significant at 0.1 .

After validating the measurement models, we examined the structural model, considering the evaluation criteria presented in table 7.

\begin{tabular}{|c|c|}
\hline \multicolumn{2}{|c|}{ Evaluation of the structural model } \\
\hline Criterion & \multicolumn{1}{c|}{ Description } \\
\hline $\begin{array}{c}\boldsymbol{R}^{2} \text { of the endogenous } \\
\text { latent variables }\end{array}$ & $\begin{array}{l}R^{2} \text { values of } 0.67,0.33 \text { and } 0.19 \text { for endogenous latent variables in the inner path } \\
\text { model are described as substantial, moderate or weak. }\end{array}$ \\
\hline $\begin{array}{c}\text { Estimates of the path } \\
\text { coefficients }\end{array}$ & $\begin{array}{l}\text { The estimated values should be evaluated in terms of the sign, magnitude and } \\
\text { significance (the last by bootstrapping). }\end{array}$ \\
\hline
\end{tabular}

Table 7 - Evaluation of the Structural Model

Source: Adapted from Henseler, Ringle \& Sinkovics (2009) and Hair, Sarstedt \& Ringle (2011)

The $R^{2}$ values of the latent variables of the structural model were: 0.715 for LGP; 0.717 for CMP; 0.492 for FP; 0.868 for PCP; and 0.536 for Performance. These values for LGP, CMP and PCP are classified as substantial, while for FP and Performance the values are considered moderate. Table 8 shows the path coefficients found, the T-statistic and the pvalue of the relationships. 
Table 8 - Path Coefficients and Significance of the Relationships of the Structural Model

\begin{tabular}{c|c|c|c|c|c|c}
\hline Relationship & $\begin{array}{c}\text { Path } \\
\text { coefficient }\end{array}$ & $\begin{array}{c}\text { Mean of the } \\
\text { bootstrapping } \\
\text { sample loadings }\end{array}$ & $\begin{array}{c}\text { Standard } \\
\text { deviation }\end{array}$ & $\begin{array}{c}\text { Standard } \\
\text { error }\end{array}$ & $\begin{array}{c}\text { T- } \\
\text { statistic }\end{array}$ & $\begin{array}{c}\text { P- } \\
\text { value }\end{array}$ \\
\hline OC -> Performance & 0.473 & 0.470 & 0.063 & 0.063 & 7.416 & $0.09 \%$ \\
\hline OS -> Performance & 0.009 & 0.041 & 0.031 & 0.031 & 0.298 & $39.02 \%$ \\
\hline HRM -> Performance & 0.306 & 0.307 & 0.059 & 0.059 & 5.164 & $0.33 \%$ \\
\hline Performance -> LGP & 0.845 & 0.847 & 0.017 & 0.017 & 47.636 & $0.00 \%$ \\
\hline Performance -> CMP & 0.846 & 0.847 & 0.016 & 0.016 & 50.633 & $0.00 \%$ \\
\hline Performance -> FP & 0.701 & 0.702 & 0.029 & 0.029 & 23.536 & $0.00 \%$ \\
\hline Performance -> PCP & 0.932 & 0.933 & 0.007 & 0.007 & 123.825 & $0.00 \%$ \\
\hline Source: Res & & & & & \\
\hline
\end{tabular}

Source: Research data.

Table 8 reveals that the construct organizational structure does not have a significant impact on organizational performance. Figure 2 presents the final model analyzed, together with the results of the PLS algorithm. 


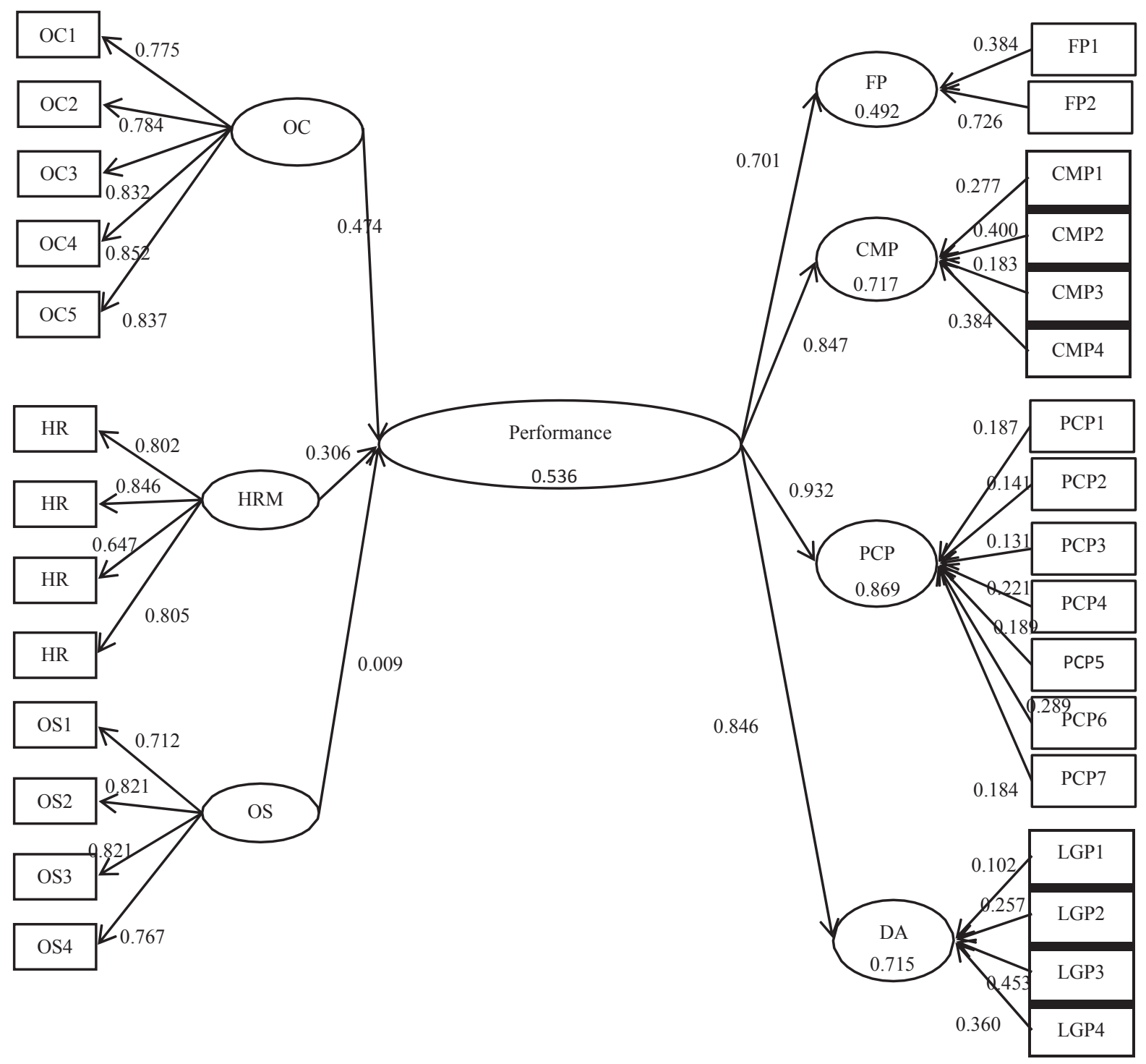

Figure 2 - Theoretical-Relational Model: Result of the Analysis Source: Research data.

The last step of the structural equations modeling was to calculate the coefficients of the structural model. When evaluating the relationships between the constructs human resource management, organizational culture and organizational structure on the one hand and organizational performance on the other, we observed the following regression equation:

Performance $=0.474 * \mathrm{OC}+0.306 * \mathrm{HRM}+0.009 * \mathrm{OS}+\varepsilon$, where $\varepsilon$ represents the error

Together the three constructs explained $53.6 \%$ of the variance of the performance of the firms in the sample, although we already found that the OS construct did not have a statistically significant relationship with performance. 


\subsection{DISCUSSION OF THE RESULTS}

The results of the SEM referring to the models to measure human resource management, organizational culture and organizational structure indicate that the three constructs and interrelated. In other words, the three spheres are correlated, evidencing the need to observe them concomitantly at the moment of implementing management by processes in organizations. This can be observed in Table 9, which shows the pairwise correlations between the constructs investigated. In this respect, $\mathrm{H} 1, \mathrm{H} 2$ and $\mathrm{H} 3$ are accepted. This result corroborates the theoretical framework, by which close relationships are mentioned of these three areas.

Table 9 - Correlation Between the Exogenous Constructs

\begin{tabular}{|c|l|l|l|}
\hline Construct & \multicolumn{1}{|c|}{ OC } & \multicolumn{1}{|c|}{ OS } & HRM \\
\hline OC & 1 & & \\
\hline OS & 0.643 & 1 & \\
\hline HRM & 0.719 & 0.600 & 1 \\
\hline
\end{tabular}

Note: All the correlations are significant at 0.01

Source: Research data

The constructs organizational culture and human resource management are significantly related to organizational performance. This confirms the initial perspective traced out that both constructs have a positive effect on the performance of the companies studied. That result indicates the need for organizations to concentrate efforts on those aspects of BPO together.

We did not find a statistically significant relationship between organizational structure and organizational performance, thus not corroborating the fourth hypothesis. This finding of non-significance of the relationship between organizational structure and organizational performance, at first glance counterintuitive, warrants further research. In this respect, future studies could investigate whether or not there is sufficient empirical evidence to affirm that organizational structure is really an independent variable or is directly associated with organizational performance, as suggested by our findings. Another aspect deserving study is to what point organizational structure (reflecting the orientation of an organization's culture and human resource management) could or should be taken as a moderator construct, necessary to achieve better performance in the context of process oriented management, associated with the organization's overall performance. 


\section{FINAL CONSIDERATIONS}

Based on the results found here, we believe it is very important to disseminate a culture focused on inter-functional and inter-organizational processes, presenting concepts regarding process oriented management and excellence of processes, with the overall aim of satisfying customers. Employees should be aware that the company is a set of interconnected processes and that their work is part of this set, important to attain the desired quality levels.

This awareness is particularly necessary for the managers involved, because they will guide the actions of their subordinates to develop specific competencies that favor process oriented management. Intra-organizational integration is very important, with focus on the flows of activities related to the different functional areas of the business. One way to promote that integration is detailed mapping of the processes and micro-processes and their documentation, so that the employees from the different departments can understand the whole and explicitly perceive where their contributions are inserted. This permits visualization of the interfaces between departments, facilitating communication, attribution of responsibilities and discovery of flaws and bottlenecks.

Preparation of training programs is also important to satisfy the principles of BPO, by improving the knowledge and skills in the theoretical and practical fields. The employees should not only be trained, but also made aware of the peculiarities of this form of management, by demonstrating to them that their knowledge is valued by the organization. Therefore, we suggest that firms prepare programs on management of competencies for processes.

The non-significance of the direct relationship between organizational structure and organizational performance suggests thinking about structure as a moderator in the formation of culture and policies on human resource management, with focus on process orientation, instead of a direct relationship with organizational performance. As seen in the theoretical framework and statistical analysis, the three constructs are closely related, which can justify this hypothesis.

As subjects for future research we can suggest: (a) formulating new variables that can measure organizational structure, to ascertain whether that variable continues to have a significant impact on organizational performance, using the four critical areas of the BSC method; (b) investigating difficulties related to human resource management inherent management by processes and the ways to overcome them; (c) treating organizational structure as a moderating construct; (d) investigating the relation between BPO and the 
maturity of processes, treating the performance of the areas of $\mathrm{BSC}$ as the dependent variable; and (e) performing in-depth qualitative studies, with case study and action research methods, to establish the relationships of the constructs studied here.

The main limitation of this study is the impossibility of generalizing the results. Although the sample size was substantial, it was too small to permit definitive and general conclusions. It is necessary to conduct similar surveys with a greater number of firms, which could corroborate or refute the results found here. Another limitation was the small amount of material found in the literature on the themes covered here, with focus on BPO/BPM. Since this is still a relatively underexplored theme, despite an extensive search in various databases, we did not find a large number of books and articles in the national and international literature.

To summarize, the results of this investigation provide evidence of relevant associations between the constructs studied, as well as relationships with low significance. We believe this paper contributes in the sense of identifying paths to enhance organizational performance in the perspective of the critical dimensions of the BSC and BPO approaches.

\section{REFERENCES}

ALBUQUERQUE, L. A gestão estratégica de pessoas IN: FLEURY, M. T. L. et al. (org.) As pessoas na organização. São Paulo: Gente, 2002.

ABPM. Association of Business Process Management Professionals. Guide to the BPM common body of knowledge, 2009.

ARMISTEAD, C.; MACHIN, S. Implications of business process management for operations management. International Journal of Operations \& Production Management, v. 17, n. 9, p. 886-898, 1997.

BALZAROVA, M. A. et al. Key success factors in implementation of process-based management. Business Process Management Journal, v. 10, n. 4, p. 387-399, 2004.

BITITCI, U.; TURNER, T. J.; BALL, P. D. The viable business structure for managing agility. International Journal of Agile Management Systems, v. 1, n. 3, p. 190-199, 1999.

BRAAM, G. J. M.; NIJSSEN, E. J. Performance effects of using the Balanced Scorecard: a note on the dutch experience. Long Range Planning, v. 37, p. 335-349, 2004.

BRONZO, M. L. et al. Processos, indicadores analíticos e impactos sobre o desempenho competitivo: um estudo em médias e grandes empresas produtoras de bens e serviços. Relatório Final do Projeto de Pesquisa. Fundação de Amparo à Pesquisa do Estado de Minas Gerais (FAPEMIG), 2011. 
BRONZO, M.; OLIVEIRA, M. P. V. A logística integrada e o desempenho de processos nos ciclos de suprimento, produção e distribuição: um estudo multisetorial das empresas industriais do Estado de Minas Gerais. Relatório Final do Projeto de Pesquisa. Fundação de Amparo à Pesquisa do Estado de Minas Gerais (FAPEMIG), 2008.

BREWER, P. C.; SPEH, T. W. Using the balanced scorecard to measure supply chain performance. Journal of Business Logistics, v. 21, n. 1, 2000.

BYRNE, J. A. The horizontal corporation. Business Week, 20 dec. 1993. Disponível em: <http://www.businessweek.com/archives/1993/b335157.arc.htm>. Acesso em: 10 nov. 2010.

CAKAR, F.; BITITCI, U.S.; MACBRYDE, J. A business process approach to human resource management. Business Process Management Journal, v. 9, n. 2, p. 190-207, 2003.

CHANDLER, A. D. Strategy and structure. Cambridge, MA: MIT Press, 1962.

CHEN, H.; MATTIODA, D. D.; DAUGHERTY, P. J. Firm-wide integration and firm performance. The International Journal of Logistics Management, v. 18, n. 2, p. 255-273, 2007.

COOPER, M. C.; LAMBERT, D. M.; PAGH, J. D. Supply chain management: more than a new name for logistics. The International Journal of Logistics Management, v. 8, n. 1, 1997.

DAVENPORT, T. H. Process innovation: reengineering work through information technology. Boston: Harvard Business School Press, 1993. 337 p.

The coming commoditization of processes. Harvard Business Review, v. 83, n. 6, p. 100-108, jun. 2005.

DETORO, I.; MCCABE, T. How to stay flexible and elude fads. Quality Progress, v. 30, p. 55-60, mar. 1997.

FORNELL, C.; LARCKER, D. F. Evaluating structural equation models with unobservable variables and measurement error. Journal of Marketing Research, v. 18, n. 1, 1981.

GONÇALVES, J. E. L. As empresas são grandes coleções de processos. Revista de Administração de Empresas, v. 40, n. 1, p. 6-19, 2000a.

GONÇALVES, J. E. L. Processo, que processo? Revista de Administração de empresas, v. 40, n. 4, p. 8-19, 2000 b.

HAIR JUNIOR, J. F. et al. Análise multivariada de dados. 6. ed. Porto Alegre: Bookman, 2009.

HAIR JUNIOR, J. F. et al. An assessment of the use of partial least squares structural equation modeling in marketing research. Journal of the Academy of Maketing Science, jun. 2011. Disponível em: <http://www.springerlink.com/content/t502155t60nv8005>. Acesso em: 07 fev. 2012.

HALL, R. H. Organizações: estruturas e processos. Rio de Janeiro: Prentice Hall do Brasil, 1984. 
HAMMER, M. Beyond reengineering: how the process-centered organization is changing our lives. New York: Harper Business, 1996.

HAMMER, M. Processed change. Journal of Business Strategy, v. 22, n. 6, p. 11-15, 2001.

HENSELER, J.; RINGLE, C. M.; SINKOVICS, R. R. The use of partial least squares path modeling in international marketing. Advances in International Marketing, v. 20, p. 277 $319,2009$.

HUSELID, M. A. The impact of human resource management practices on turnover, productivity, and corporate financial performance. Academy of Management Journal, v. 38, n. 3, p. 635-872, 1995.

KAPLAN, R. S.; NORTON, D. P. The balanced scorecard. Harvard College: USA, 1996.

KOHLBACHER, M. The effects of process orientation: a literature review. Business Process Management Journal, v. 16, n. 1, p. 135-152, 2010.

LEE, R. G.; DALE, B. G. Business process management: a review and evaluation. Business Process Management Journal, v. 4, n. 3, p. 214-225, 2004.

LOVE, P. E. D.; GUNASEKARAN, A.; LI, H. Putting an engine into re-engineering: toward a process-oriented organization. International Journal of Operations \& Production Management, v. 18, n. 9/10, p. 937-949, 1998.

MCCORMACK, K.; JOHNSON, W. Business process orientation: gaining the e-business competitive advantage. Boca Raton: CRC Press LLC, 2001. p. 209.

MCCORMACK, K.; JOHNSON, W.; WALKER, W. Supply chain networks and business process orientation: advanced strategies and best pratices. APICS series on resource management. Boca Raton, Florida: CRC Press LLC, 2003.

MARTIN, J. Cultures in organizations: three perspectives. New York: 1992.

MINTZBERG, H. Criando organizações eficazes: estruturas em cinco configurações. 2. ed. São Paulo: Atlas, 2008.

MORGAN, G. Imagens da organização. 2. ed. São Paulo: Atlas, 2002.

NEELY, A. et al. Performance measurement system design: developing and testing a processbased approach. International Journal of Operations \& Prodution Managemet, v. 20, n. 10, p. 1.119-45, 2000.

NEELY, A. et al. Designing performance measures: a structured approach. International Journal of Operations \& Production Management, v. 17, n. 11, p. 1131-1152, 1997.

NETEMEYER, R. G.; BEARDEN, W. O.; SHARMA, S. Scaling procedures: issues and applications. Thousand Oaks (CA): SAGE, 2003.

PALMBERG, K. Experiences of implementing process management: a multiple-case study, Business Process Management Journal, v. 16, n. 1, p. 93-113, 2010. 
RINGLE, C. M.; WENDE, S.; WILL, A. SmartPLS 2.0 M3. 2005. Disponível em: <http:// www.smartpls.de>. Acesso em: 16 fev. 2012.

SIDOROVA, A.; ISIK, O. Business process research: a cross-disciplinary review. Business Process Management Journal, v. 16, n. 4, p. 566-597, 2010.

SKRINJAR, R.; TRKMAN, P. Increasing process orientation with business process management: critical practices. International Journal of Information Management, v. 33, p. $48-60,2013$.

TABACHNICK, B. G.; FIDELL, L. S. Using multivariate statistics. 5. ed. Boston: Pearson Education, 2007.

TENNER, A. R.; DETORO, I. J., Process redesign: the implementation guide for managers. New Jersey: Prentice Hall, 2000.

VIAENE, S. et al. BPM: quo vadis? BP Trends, set. 2010.

WILLAERT, P. et al. The process-oriented organisation: a holistic view. Developing a framework for business process orientation maturity. In: INTERNATIONAL BPM CONFERENCE, 5., 2007, Brisbane (AUS). Anais... Brisbane: BPM, 2007. p. 24-7.

WOLD, H. Soft modeling: the basic design and some extensions. In: JÖRESKOG, K. G.; WOLD, H. (Eds.), Systems under indirect observation: causality, structure, prediction. North-Holland: Amsterdam, 1982. Part I, p. 1-54.

ZAIRI, M. Business process management: a boundaryless approach to modern competitiveness. Business Process Management Journal, v. 3, n. 2, 1997.

ZUCCHI, F.; EDWARDS, J. S. Human resource management aspects of business process reengineering: a survey. Business Process Management Journal, v. 5, n. 4, 1999. 